\title{
COMPARISON OF ANALYTICAL PARAMETERS OF BEER BREWED IN TWO DIFFERENT TECHNOLOGICAL WAYS AT TWO PUB BREWERIES
}

\author{
P. Kryl, T. Gregor, J. Los
}

Received: March 5, 2012

\begin{abstract}
KRYL, P., GREGOR, T., LOS, J.: Comparison of analytical parameters of beer brewed in two different technological ways at two pub breweries. Acta univ. agric. et silvic. Mendel. Brun., 2012, LX, No. 5, pp. 137-144

This publication deals with brewing beer by infusion and decoction technologies of mash production in microbreweries. Samples of two microbrewery beers are compared, namely Richard beer (BrnoŽebětín) produced in a double mash manner appropriate for the Czech brewing type, and beer samples taken at the laboratory microbrewery of Mendel University in Brno (MENDELU), where beer is produced in a simpler and less energy - demanding infusion method. At all the beer samples the basic analytical parameters of real extract, ethanol content, degree of fermentation and the extract of original hopped wort were measured using an automatic beer analyzer. The results coming out of the automatic beer analyzer are compared with the results of the beer samples analysis performed by liquid chromatography, by which the contents of oligosaccharides, maltose, glycerol and ethanol were measured. Both methods provide a number of analytical results for the comparison of decoction and infusion techniques, and analytical characteristics of both the brewing procedures. Emphasis is placed on statistical data processing and comparison of different types of beer and particular brews between each other, both in terms of production technology as well as beer sampling throughout the year.
\end{abstract}

production of beer, decoction, infusion, real extract, degree of fermentation, ethanol content

Mashing is one of the most important steps in the beer brewing process and the final quality and type of beer produced will depend on the way it is performed. Its aim is to produce malt wort and then brewing it with hops to create the hopped wort containing fermentable carbohydrates, dextrin, substances of nitrogen nature for yeast nutrition and other polyphenols and aromatic compounds. The composition of the malt wort depends on the temperature profile during mashing (Koljonen, 1995). Due to enzymatic processes during mashing the macromolecular substances such as starch and proteins are split into substances of lower molecular weight. Starch is split into dextrins, oligosaccharides and fermentable carbohydrates, proteins are split into peptides, oligopeptides and amino acids. Each group of these substances in the finished beer has an indispensable function and thanks to the yeast, which transformed the quantity of substances, a colloidal system of beer is formed (Freeman, 2003).

The mashing process can be divided into decoction and infusion way. Both of them begin in the same way, bruised malt is poured into water at a temperature usually $37-52{ }^{\circ} \mathrm{C}$, this phase is called primordial mash. In subsequent phases, the temperature is being gradually increased reaching optimum for each range where certain groups of enzymes are the most active. At temperatures around $37{ }^{\circ} \mathrm{C}$ the most active are phosphatases, from $40-55{ }^{\circ} \mathrm{C}$ proteases, around $58-65{ }^{\circ} \mathrm{C} \beta-$ amylases are activated and $\alpha$-amylases around 70 $72{ }^{\circ} \mathrm{C}$. In addition to these basic groups of enzymes, 
where the individual temperature phases overlap each other, other enzymes involved in the final composition of the malt wort are activated, too. In the infusion process, the mash is heated gradually according to the brewing scheme, and the mashing is carried out in one container, which makes the process simpler and less energy consuming. With the decoction technology process, a part of the mash is heated separately from the rest, usually brought to the boiling point. Then the hot mash is delivered back to the rest, which always brings it all to a higher temperature. This procedure is repeated with the mash portions usually two or three times, and so this technological process is called accordingly, i.e. double or triple mash procedure (MacGregor, 1999).

A typical method for the production of Czech beer is the one of decoction, usually double mash (Silva, 2008). In using decoction way a lot of aromatics substances arise in the malt wort which does not occur with the infusion method. In the hopped wort thus obtained there are also a lot of not fermentable oligosaccharides which have a beneficial effect on the sensory quality of beer, usually increasing the fullness of beer. Beers produced in the decoction way tend to have a lower degree of fermentation due to higher content of not fermentable oligosaccharides, less alcohol and a higher content of the real extract than beers produced in the infusion way (Hoops, 2009). Infusion technology compared to the decoction one demands about $20 \%$ less energy and saves about 18\% time (Montanari, 2005).

\section{MATERIALS AND METHODS}

\section{Microbreweries and Technology}

The Richard Brewery in Brno-Žebětín was built in 2004 with a rather large brewing house of $10 \mathrm{hl}$ in volume for a pub brewery. It has not been upgraded in any way up to now, only a few tanks were added in the storage cellar with the capacity of $30 \mathrm{hl}$ each. It is a manual microbrewery made of stainless steel with automatic temperature control, equipped with a temporal electrical steam heating and direct cooling of the storage cellar. The main fermentation takes place in open fermenting rooms of 10 and $20 \mathrm{hl}$ in volume. The storage cellar currently has a total capacity of $120 \mathrm{hl}$. Currently, there are 4 beers to offer that have been analyzed.

The MENDELU brewery is to be found as a laboratory microbrewery at the Mendel University in Brno, with the brewing kit of $1 \mathrm{hl}$ in volume. It was designed as a laboratory for the production of batches of beer primarily intended for laboratory experiments. It was built in 2005, of stainless steel, manually controlled with an automatic temperature regulation. Heating of the mash - hopped wort tub is performed electrically by heating oil, and the cellar, consisting of only two lager tanks, is equipped with a cooling system. The advantage of the MENDELU microbrewery is in its small capacity, enabling the manufacturer to provide various batches of beer, mostly for experimental purposes of the university and surrounding breweries. The parameters of the two breweries are shown in Tab. I.

I: Parameters of Microbrewery Richard and MENDELU

\begin{tabular}{|c|c|c|c|c|}
\hline \multirow{2}{*}{ Parameter } & \multicolumn{4}{|c|}{ Brewery } \\
\hline & & Richard & & Mendelu \\
\hline Brewing house volume & & $10 \mathrm{hl}$ & & Ihl \\
\hline \multirow{3}{*}{ Number of brewing tanks / functions } & \multirow{3}{*}{3} & Mash-hopped wort & \multirow{3}{*}{2} & $\begin{array}{c}\text { Mash - hopped wort and } \\
\text { whirling }\end{array}$ \\
\hline & & Filtering off & & \multirow{2}{*}{ Filtering off } \\
\hline & & whirling & & \\
\hline Type of heating & & Electrically - steam & & Electrically - oil \\
\hline Type of stirring & & Stirrer & & Pump (circulation) \\
\hline One batch production time & & $10 \mathrm{~h}$ & & $12 \mathrm{~h}$ \\
\hline Fermenting room & & $30 \mathrm{hl}$ & & $1 \mathrm{hl}$ \\
\hline Cylindrical - conic tanks & & $3 \times 20 \mathrm{hl}$ & & $1 \times 1 \mathrm{hl}$ \\
\hline Lager tanks & & $6 \times 20 \mathrm{hl}$ & & $2 \times 1 \mathrm{hl}$ \\
\hline Cellar cooling & & Direct by air & & Cooling liquid \\
\hline Amount of hopped wort produced & & $10 \mathrm{hl}$ & & lhl \\
\hline Utilized area & & $150 \mathrm{~m}^{2}$ & & $40 \mathrm{~m}^{2}$ \\
\hline Prevailing technology & & decoction - double mash & & infusion \\
\hline Number of types of beer & & 4 & & 8 \\
\hline Volume of beer produced annually & & $3000 \mathrm{hl}$ & & $54 \mathrm{hl}$ \\
\hline Control & & manual - thermostat & & manual - thermostat \\
\hline
\end{tabular}




\section{Beers observed and adjustment of the samples for the analysis}

The beers observed for the aim of our analysis are those produced at the above mentioned breweries. The Richard microbrewery permanently offers 4 beers, the MENDELU brewery, due to its capacity, produces about 8 beers. For beers to be tested and preparation of samples for our analysis and comparison purposes, only 2 kinds of beer were chosen, on which the required number of samplings and repetitions were performed. All the beers were made from drinking water taken from water mains (Veolia, Brno, Czech Republic), from light pilsner malt (Bernard Malting Plant, a. s., Rajhrad, Czech Republic), at Richard wheat beer also with 30\% wheat malt substitute for barley malt (Malting Plant Litovel, Czech Republic), hops are used Zatec semi - early red, Premiant and Sladek (Hop Research Institute Ltd., Zatec, Czech Republic) and bottom fermenting yeast - strain No. 95 (VÚPS, a. s., Prague, Czech Republic).

The beers to be analyzed were freed of carbon dioxide by means of Erlenmeyer shaking flask. The beer samples can be seen in Tab. II.

\section{Characteristics of the observed parameters}

The content of ethanol - the amount of ethanol produced from the extract (fermentable saccharides) of the hopped wort by the brewer's yeast fermentation (\% wt or \% vol.).

Extract of the original hopped wort (original proof) - the content of the dissolved solids in the original hopped wort it is determined in weight percentage (\% wt).

The real extract - the content of the dissolved substances in the de - carbonated beer (freed of carbon dioxide by shaking it out) and ethanol (by distillation) filled up with water to the original weight (\% wt.).

The degree of fermentation - is the loss of real extract during the fermentation process, expressed in percentage (\%).

\section{Analytical methods}

The automatic beer analyzer Fermentostar (Funke - Gerber, France) is a device designed for the analysis of beer and all its intermediate products. It was by means of this device that the above mentioned parameters were determined. The measurement is based on methods of thermo analytical measuring combined with mathematical algorithms. The manufacturer specifies the accuracy of each measurement resolution as $0.01 \%$ for each of the measured parameters.

HPLC analysis was used (Ecom Ltd., Czech Republic). De - ionized water was used in its mobile phase, column temperature $50^{\circ} \mathrm{C}$, mobile phase flow rate $0.5 \mathrm{ml}$ ( $\mathrm{min}, 50 \times 4 \mathrm{~mm}$ steel pre - column (Watrex, Germany), filling of the pre column HEMA BIO Q + Sb $10 \mu \mathrm{m}$, steel analytical column $8 \times 250 \mathrm{~mm}$ (Watrex, Germany), filling of the column Ostion LG KS $0800 \mathrm{Ca}^{2+} 10 \mu \mathrm{m}, 5 \mathrm{ml}$ of sample injection, working pressure of $8.3 \mathrm{MPa}$, refractometric detection. Clarity version 2.1.231 was used for the evaluation of the programme.

\section{Processing and evaluation of the results}

All analytical measurements were carried out in three repetitions on samples always taken in pairs. Evaluation of the data was performed using a single - factor analysis of variance followed by verifying the conclusive evidence of differences according to Tukey. For all the data files the Cochran variance homogeneity test was carried out. The dependencies among the selected factors were evaluated by means of the variance analysis according to Duncan and the correlation coefficients calculated to the level of significance of $95 \%$. The evaluation was performed by using Statistica 9.0 (StatSoft, Czech Republic).

\section{RESULTS AND DISCUSSION}

The collected samples were tested by means of the automatic beer analyzer to determine the real extract, alcohol content, original proof of the hopped wort and the degree of fermentation. As seen in Tab. III, $12^{\circ}$ beer produced from barley malt shows substantial fluctuations during the observation period which are most significant at the achievable degree of fermentation, where the values range from 74 to $81.9 \%$. These fluctuations are connected with slightly fluctuating values of the real extract, which ranged from 3.8 to 4.2 vol. \%, and alcohol content, which ranged from 3.4 to $4.1 \%$ wt. According to Basarova (2010) these fluctuations may be caused by different conditions under which fermentation of hopped wort takes place. Council Regulation (EC) No. 510/2006, however, states as the maximum attainable value for the degree of fermentation $82 \%$. Our tested sample of $12^{\circ}$ beer thus meets the regulatory requirements in some cases only by $0.2 \%$, which is very close to the limit.

II: The analyzed beers from the breweries of Richard and MENDELU.\%: ${ }^{\circ} \mathrm{P}$ (Plato) coleration of temperature on $17.5^{\circ} \mathrm{C}$

\begin{tabular}{|l|l|}
\hline \multicolumn{2}{|c|}{ brewery (technology of production) } \\
\hline \multicolumn{1}{|c|}{ Richard (decoction) } & \multicolumn{1}{c|}{ Mendelu (infusion) } \\
\hline $11 \%$ - wheat pale lager beer & $11 \%$ - barley pale lager beer \\
\hline $12 \%$ - barley pale lager beer & $15 \%$ - pale honey lager beer \\
\hline $12 \%$ - cherry lager beer & \\
\cline { 1 - 1 } $15 \%$ - pale honey lager beer & \\
\hline
\end{tabular}


III: The values of the real content of the extract, ethanol extract of original wort and degree of fermentation in the samples taken from the Richard Brewery beers

\begin{tabular}{|c|c|c|c|c|c|c|c|c|c|c|c|c|c|c|c|c|}
\hline $\begin{array}{c}\text { time of } \\
\text { sampling }\end{array}$ & \multicolumn{4}{|c|}{$\begin{array}{l}\text { real extract } \\
\mathrm{g} / 100 \mathrm{~g}\end{array}$} & \multicolumn{4}{|c|}{$\begin{array}{l}\text { ethanol } \\
\mathrm{g} / 100 \mathrm{~g}\end{array}$} & \multicolumn{4}{|c|}{$\begin{array}{l}\text { original extract of wort } \\
\mathrm{g} / 100 \mathrm{~g}\end{array}$} & \multicolumn{4}{|c|}{$\begin{array}{l}\text { degree of fermentation } \\
\%\end{array}$} \\
\hline & & & & & & $\begin{array}{c}12^{\circ} \\
\text { cherry }\end{array}$ & & & & & & & & $\begin{array}{c}12^{\circ} \\
\text { cherry }\end{array}$ & & $\begin{array}{c}15^{\circ} \\
\text { honey }\end{array}$ \\
\hline & 4,0 & & 37 & & 10 & & & & & & & & & & & 3 \\
\hline $2 / 20$ & & & 3,6 & $5, \mathrm{C}$ & 4, & 4,0 & $3, r$ & 6 , & 11,9 & 11,8 & 10,9 & 16,0 & 81 & 82,0 & 81,1 & 88,9 \\
\hline $3 / 2$ & & & & 4,8 & & 3 , & & & 11 & 1, & U & 15 & 79 & 30,1 & 78 & 89,1 \\
\hline $4 / 2$ & & & 3,1 & 4, & & 3,9 & 3,6 & 6, & 11,8 & 11, & 11 & 15,6 & 79 & 80,0 & 7 & 88,8 \\
\hline $5 / 20$ & 4,2 & 4,1 & 3,7 & 4,9 & 3, & 3,7 & 3,6 & 6,2 & 12,2 & 12,0 & 10 & 16,0 & 76 & 78,6 & 79,2 & 91,3 \\
\hline $6 / 20$ & & & 3, & 4 & & 3 & & & 12 & 11 , & 11 & 15,9 & 76 & 77,1 & 76 & 88,6 \\
\hline $7 / 20$ & 4,0 & 3,9 & 3,7 & 4,7 & 3, & 3,9 & 3,5 & 6 & 11,9 & 11,7 & 10 & 15,5 & 78 & 79,5 & 77,4 & 90,9 \\
\hline $8 / 20$ & 4,0 & & 3,8 & 4, & & 3,7 & 3 , & & 11,8 & 11,6 & 11 & 15,8 & 77 & 78,6 & 79,9 & 90,0 \\
\hline & 4,1 & & 3,7 & 4 , & & 3,9 & 3,5 & 6 & 12,2 & 11,9 & 10,8 & 15,7 & 80 & 81,5 & 76,5 & 91,5 \\
\hline & 3,9 & 3,9 & 3,6 & 5,0 & & 3,9 & 3,7 & 6 , & 11,9 & 11,7 & 11,0 & 16,0 & 79,8 & 80,2 & 82,0 & 88,4 \\
\hline $11 / 201$ & 4 & 4,0 & 3, & 4, & 4, & 4,0 & 3,7 & 6 & 12,2 & 12,0 & 11,1 & 15,8 & 80,3 & 81,7 & 81,8 & 88,4 \\
\hline $12 / 2011$ & 3,8 & 3,5 & 3,7 & 4,7 & 3,4 & 3,9 & 3,7 & 6,2 & 11,0 & 10,9 & 11,2 & 15,6 & 74,0 & 75,2 & 81,7 & 90,9 \\
\hline
\end{tabular}

The statistical analysis shows very convincingly the growing dependence of the alcohol content on the real extract $(p=0.001816)$. Also, the growing dependence of the degree of fermentation on the real extract is statistically significant $(\mathrm{p}=0.031411)$, as well as high alcohol content dependence on the degree of fermentation ( $p=0.00001)$, which directly relates to the fact that the more fermented the hopped wort, the more ethanol gets into it. In assessing the relation of alcohol content with the original proof of the hopped wort, these two quantities are not statistically related ( $p=0.132021)$.

Tab. III shows the measured values of honey beer which apparently indicate a higher degree of fermentation. This is due to honey surrogation, which is characteristic for this beer. The linden honey, used here, contains monosaccharides such as fructose and glucose, which together with maltose, ferment fast and first, results in higher degree of fermentation and, consequently, in lesser content of the real extract. It may have an impact on the taste of beer as the beer may seem to be not so full (Carvalho, 2009).

Cherry beer produced at the Richard brewery is not a real cider, for cider is usually produced by fermentation of hopped wort with added fruit must (Blanco - Gomis, 2007). At the Richard brewery, they add fruit syrup to the finished $12^{\circ}$ beer. The values of cherry beer are very close to those measured at $12^{\circ}$ beer brewed from barley malt, the only difference being in increased values of the real extract caused by the addition of fruit syrup to the finished beer. Carbohydrates, which are contained in the cherry syrup, increase the content of extractive substances in beer (Verstrepen, 2003). The addition of syrup causes a decrease in the alcohol content of beer due to the dilution, while the content of the real extract increases, thereby reducing the value of the fermentation.

As for the wheat beer, it is made with a portion of wheat malt whose fermentation takes place in a more heterogeneous way. Thanks to the wheat malt the fermentation is faster and it is accompanied by the growth of specific substances such as aldehydes, ketones, alcohols and esters, all of which affect the sensory character of beer (Fritsch, 2005). As shown in Table III, during the whole year only slight variations occurred in the observed parameters in the production of wheat beer. It gives relevant evidence $(p=0.009204)$ of the degree of fermentation and the real extract, then the alcohol content and the degree of fermentation $(\mathrm{p}=0.014330)$ and the alcohol dependence on the real extract $(p=0.024103)$. As in previous cases, the dependence of alcohol content on the original proof of the hopped wort does not show statistically any relation ( $\mathrm{p}=0.567014)$.

The samples were also analyzed by means of HPLC. Among the observed parameters of beer ranked the content of oligosaccharides, maltose, glycerol and ethanol. Glucose and traceable amounts of fructose were found and measured in some cases in young beers, but in the finished beer their contents were below the limit of determination and therefore they are not shown in Tab. IV.

The measured values of the ethanol content found in $12^{\circ}$ beer in Tab. IV correspond to the qualitative parameters of Czech beer, according to Council Regulation EC No. 510/2006, which determines the ethanol content of lager in the range of 3 to $4.8 \% \mathrm{wt}$ (3.8 to 6.0 vol. \%).

The measured values of cherry beer follow the same pattern as with $12^{\circ}$ beer. Cherry beer was made in the same way as $12^{\circ}$ beer, with only one exception and that is the addition of cherry syrup to the finished beer. This fact is also reflected in the increased content of all measured saccharides.

In comparison with other kinds of beer, the honey beer showed higher maltose content which may be the result of, among other things, the addition of honey, which contains glucose and fructose, which get fermented first during the fermentation. The 
IV: The content of oligosaccharides, maltose, glycerol and ethanol measured by liquid chromatography in samples of beer from the Richard brewery

\begin{tabular}{|c|c|c|c|c|c|c|c|c|c|c|c|c|c|c|c|c|}
\hline $\begin{array}{c}\text { time of } \\
\text { sampling }\end{array}$ & \multicolumn{4}{|c|}{$\begin{array}{l}\text { oligasaccharides } \\
\qquad \mathrm{g} / 100 \mathrm{~g}\end{array}$} & \multicolumn{4}{|c|}{$\begin{array}{l}\text { maltose } \\
\mathrm{g} / 100 \mathrm{~g}\end{array}$} & \multicolumn{4}{|c|}{$\begin{array}{l}\text { glycerol } \\
\mathrm{g} / 100 \mathrm{~g}\end{array}$} & \multicolumn{4}{|c|}{$\begin{array}{l}\text { ethanol } \\
\mathrm{g} / 100 \mathrm{~g}\end{array}$} \\
\hline onth / year & $\begin{array}{c}12^{\circ} \\
\text { barley }\end{array}$ & $\begin{array}{c}12^{\circ} \\
\text { cherry }\end{array}$ & $\begin{array}{l}11^{\circ} \\
\text { wheet }\end{array}$ & $\begin{array}{c}15^{\circ} \\
\text { honey }\end{array}$ & $\begin{array}{c}12^{\circ} \\
\text { barley }\end{array}$ & $\begin{array}{c}12^{\circ} \\
\text { cherry }\end{array}$ & $\begin{array}{l}11^{\circ} \\
\text { wheet }\end{array}$ & $\begin{array}{c}15^{\circ} \\
\text { honey }\end{array}$ & $\begin{array}{c}12^{\circ} \\
\text { barley }\end{array}$ & $\begin{array}{c}12^{\circ} \\
\text { cherry }\end{array}$ & $\begin{array}{l}11^{\circ} \\
\text { wheet }\end{array}$ & $\begin{array}{c}15^{\circ} \\
\text { honey }\end{array}$ & $\begin{array}{l}12^{\circ} \\
\text { barley }\end{array}$ & $\begin{array}{l}12^{\circ} \\
\text { cherry }\end{array}$ & $\begin{array}{c}11^{\circ} \\
\text { wheet }\end{array}$ & $\begin{array}{c}15^{\circ} \\
\text { honey }\end{array}$ \\
\hline $1 / 2011$ & 3,9 & 3,4 & 3,3 & 5,1 & 0,6 & 0,5 & 0,5 & 0,9 & 0,2 & 0,1 & 0,2 & 0,4 & 3,9 & 3,9 & 3,6 & 6,2 \\
\hline $2 / 2011$ & 4,1 & 4,0 & 4,1 & 4,7 & 0,7 & 0,5 & 0,7 & 0,9 & 0,1 & 0,1 & 0,1 & 0,5 & 4,1 & 3,9 & 3,7 & 5,9 \\
\hline $3 / 2011$ & 4,2 & 3,7 & 3,9 & 4,7 & 0,6 & 0,7 & 0,5 & 0,8 & 0,2 & 0,1 & 0,1 & 0,3 & 4,0 & 3,9 & 3,6 & 6,0 \\
\hline $4 / 2011$ & 4,2 & 4,1 & 4,0 & 4,9 & 0,5 & 0,6 & 0,7 & 1,0 & 0,2 & 0,1 & 0,2 & 0,3 & 4,0 & 3,9 & 3,6 & 5,9 \\
\hline $5 / 2011$ & 4,0 & 4,1 & 4,2 & 4,5 & 0,7 & 0,5 & 0,5 & 0,7 & 0,1 & 0,1 & 0,1 & 0,3 & 3,8 & 3,8 & 3,6 & 6,2 \\
\hline $6 / 2011$ & 4,2 & 4,2 & 4,1 & 4,7 & 0,5 & 0,5 & 0,5 & 0,9 & 0,2 & 0,1 & 0,1 & 0,3 & 3,9 & 3,7 & 3,5 & 6,1 \\
\hline $7 / 2011$ & 3,8 & 3,9 & 3,9 & 4,4 & 0,5 & 0,6 & 0,6 & 0,9 & 0,2 & 0,1 & 0,1 & 0,4 & 4,0 & 3,9 & 3,5 & 6,2 \\
\hline $8 / 2011$ & 3,9 & 3,9 & 4,0 & 5,0 & 0,6 & 0,5 & 0,5 & 0,9 & 0,1 & 0,1 & 0,2 & 0,5 & 3,9 & 3,9 & 3,6 & 6,1 \\
\hline 9/2011 & 4,1 & 4,0 & 4,1 & 4,3 & 0,6 & 0,6 & 0,6 & 0,8 & 0,2 & 0,2 & 0,2 & 0,4 & 3,9 & 3,8 & 3,5 & 6,2 \\
\hline $10 / 2011$ & 3,8 & 4,2 & 3,9 & 5,0 & 0,6 & 0,5 & 0,6 & 0,9 & 0,1 & 0,1 & 0,1 & 0,3 & 4,0 & 3,9 & 3,8 & 6,1 \\
\hline $11 / 2011$ & 3,9 & 4,0 & 3,8 & 5,0 & 0,6 & 0,6 & 0,5 & 0,9 & 0,1 & 0,2 & 0,2 & 0,3 & 4,1 & 3,9 & 3,7 & 6,2 \\
\hline $12 / 2011$ & 3,8 & 4,0 & 3,8 & 4,6 & 0,5 & 0,7 & 0,6 & 0,9 & 0,2 & 0,1 & 0,1 & 0,4 & 3,4 & 3,9 & 3,7 & 6,1 \\
\hline
\end{tabular}

V: The values of the content of the real extract, ethanol extract of original hopped wort and degree of fermentation in the samples taken at the MENDELUbrewery

\begin{tabular}{|c|c|c|c|c|c|c|c|c|}
$\begin{array}{c}\text { time of } \\
\text { sampling }\end{array}$ & \multicolumn{2}{|c|}{$\begin{array}{c}\text { real extract } \\
\mathbf{g} / \mathbf{1 0 0} \mathbf{g}\end{array}$} & \multicolumn{2}{c|}{$\begin{array}{c}\text { ethanol } \\
\mathbf{g} / \mathbf{1 0 0} \mathbf{g}\end{array}$} & $\begin{array}{c}\text { original extract of wort } \\
\mathbf{g} / \mathbf{1 0 0} \mathbf{g}\end{array}$ & \multicolumn{2}{c|}{$\begin{array}{c}\text { degree of fermentation } \\
\%\end{array}$} \\
\hline month / year & $11^{\circ}$ barley & $15^{\circ}$ honey & $11^{\circ}$ barley & $15^{\circ}$ honey & $11^{\circ}$ barley & $15^{\circ}$ honey & $11^{\circ}$ barley & $15^{\circ}$ honey \\
\hline $1 / 2011$ & 4,2 & 4,5 & 3,7 & 6,1 & 11,4 & 16,7 & 78,9 & 90,1 \\
\hline $2 / 2011$ & 4,1 & 4,3 & 3,8 & 6,2 & 11,6 & 16,7 & 80,1 & 90,4 \\
\hline $3 / 2011$ & 4,2 & 4,7 & 3,9 & 5,8 & 11,8 & 16,3 & 80,2 & 88,6 \\
\hline $4 / 2011$ & 3,8 & 4,3 & 3,8 & 5,9 & 11,3 & 16,1 & 81,9 & 89,1 \\
\hline $5 / 2011$ & 4,1 & 4,5 & 3,8 & 6,2 & 11,5 & 17,0 & 80,2 & 88,7 \\
\hline $6 / 2011$ & 4,8 & 4,2 & 3,5 & 6,0 & 11,6 & 16,2 & 74,2 & 90,2 \\
\hline $7 / 2011$ & 3,9 & 4,1 & 3,5 & 5,8 & 10,7 & 15,7 & 78,2 & 90,8 \\
\hline $8 / 2011$ & 3,4 & 4,3 & 3,1 & 5,7 & 9,6 & 15,7 & 80,1 & 90,1 \\
\hline $9 / 2011$ & 3,1 & 4,1 & 3,6 & 6,2 & 10,1 & 16,6 & 84,2 & 90,4 \\
\hline $10 / 2011$ & 4,2 & 4,4 & 3,6 & 6,0 & 11,3 & 16,5 & 78,6 & 89,7 \\
\hline $11 / 2011$ & 4,1 & 4,1 & 3,8 & 5,8 & 11,6 & 15,7 & 80,1 & 89,4 \\
\hline $12 / 2011$ & 3,8 & 4,0 & 3,8 & 6,1 & 11,3 & 16,2 & 81,9 & 90,8 \\
\hline
\end{tabular}

increased ethanol content in beer then does not make the yeast to utilize energetically less favourable maltotriose and disaccharides, which are in the real extract at higher concentrations than in beer without the addition of honey. Also, the glycerol concentration was the highest in honey beer in comparison with all the other observed kinds of beer, which is related to the content of fermentable sugars at the beginning of fermentation. With higher concentrations of monosaccharides in the hopped wort, higher amount of glycerol may be produced by the yeast due to their metabolic paths (Silva, 2008). This phenomenon was found also in the honey beer produced by infusion method in the MENDELU brewery (Tab. VI). Glycerol has important sensory properties which influence the fullness of taste as it prolongs the feeling of bitterness (Oliveira, 2006). Thanks to its honey addition, the honey beer has also the highest content of oligosaccharides and, consequently, the highest content of ethanol.
Of the MENDELU brewery only two beers were observed as only these two samples met the desired brewing frequency throughout the year, despite the wide range of beers produced there. Compared to beers produced in the Richard brewery, all Mendelu brewery beers are brewed by the infusion method. This is also seen in the analytical parameters of thus produced beers (Tab. V). Statistically significant difference in the real extract ( $p=0.04054)$ is seen comparing Richard $11^{\circ}$ beer with MENDELU $11^{\circ}$ beer, where the beer brewed by infusion technique (MENDELU) is on average higher by $0.3 \%$. This difference does not give evidence to the opposite trend that the beers produced by infusion method tend to have a lower value of the real extract. This is due to differences in materials used in each beer, in the first case it is barley (infusion) and in the second case it is wheat malt (decoction). Due to its more complex protein matrix, the wheat malt does not reach such values of released nitrogen compounds as barley malt, and that is why the real extract of 
VI: The content of oligosaccharides, maltose, glycerol and ethanol measured by liquid chromatography in samples of beerfrom MENDELU brewery

\begin{tabular}{|c|c|c|c|c|c|c|c|c|}
$\begin{array}{c}\text { time of } \\
\text { sampling }\end{array}$ & \multicolumn{2}{|c|}{$\begin{array}{c}\text { oligasaccharides } \\
\mathbf{g} / \mathbf{1 0 0} \mathbf{g}\end{array}$} & \multicolumn{2}{c|}{$\begin{array}{c}\text { maltose } \\
\mathbf{g} / \mathbf{1 0 0} \mathbf{~ g}\end{array}$} & \multicolumn{2}{c|}{$\begin{array}{c}\text { glycerol } \\
\mathbf{g} / \mathbf{1 0 0} \mathbf{~ g}\end{array}$} & \multicolumn{2}{c|}{$\begin{array}{c}\text { ethanol } \\
\mathbf{g} / 100 \mathrm{~g}\end{array}$} \\
\hline month / year & $11^{\circ}$ barley & $\mathbf{1 5 ^ { \circ } \text { honey }}$ & $\mathbf{1 1 ^ { \circ } \text { barley }}$ & $\mathbf{1 5 ^ { \circ } \text { honey }}$ & $\mathbf{1 1 ^ { \circ } \text { barley }}$ & $\mathbf{1 5 ^ { \circ } \text { honey }}$ & $\mathbf{1 1 ^ { \circ } \text { barley }}$ & $15^{\circ}$ honey \\
\hline $1 / 2011$ & 3,6 & 4,5 & 0,5 & 0,7 & 0,1 & 0,7 & 3,8 & 6,2 \\
\hline $2 / 2011$ & 4,0 & 4,7 & 0,5 & 0,8 & 0,3 & 0,8 & 3,9 & 6,3 \\
\hline $3 / 2011$ & 3,8 & 4,6 & 0,4 & 0,7 & 0,2 & 0,4 & 3,9 & 5,9 \\
\hline $4 / 2011$ & 4,1 & 4,4 & 0,6 & 0,6 & 0,1 & 0,6 & 4,0 & 6,0 \\
\hline $5 / 2011$ & 3,8 & 4,8 & 0,4 & 0,8 & 0,1 & 0,5 & 3,9 & 6,4 \\
\hline $6 / 2011$ & 3,9 & 4,6 & 0,5 & 0,7 & 0,2 & 0,5 & 3,6 & 6,1 \\
\hline $7 / 2011$ & 4,2 & 4,5 & 0,6 & 0,6 & 0,1 & 0,6 & 3,6 & 5,9 \\
\hline $8 / 2011$ & 4,1 & 4,4 & 0,6 & 0,7 & 0,1 & 0,5 & 3,4 & 5,6 \\
\hline $9 / 2011$ & 4,1 & 4,7 & 0,5 & 0,8 & 0,1 & 0,7 & 3,7 & 6,2 \\
\hline $10 / 2011$ & 3,7 & 4,6 & 0,5 & 0,7 & 0,2 & 0,8 & 3,7 & 6,1 \\
\hline $11 / 2011$ & 4,0 & 4,7 & 0,4 & 0,6 & 0,1 & 0,6 & 3,8 & 5,9 \\
\hline $12 / 2011$ & 4,1 & 4,8 & 0,5 & 0,6 & 0,2 & 0,7 & 3,9 & 6,0 \\
\hline
\end{tabular}

wheat beers is impoverished of these parts and the resulting content is therefore smaller. The other parameters such as ethanol content, original proof of the hopped wort and the fermentation stage are not in this type of beer statistically significant at the $95 \%$ level. In contrast, the parameters of both $15^{\circ}$ honey specials significantly differ from each other in the real extract content, ethanol content and original proof of the hopped wort $(p=0.000144$, $p=0.037787, p=0.001764)$. As for the fermentation stage, the two $15^{\circ}$ honey specials are not different $(p=0.776214)$. The real extract in the decoction way brewed beer is on average 0.5\% higher in comparison with the infusion technique, and also ethanol content is higher by $0.2 \%$. The original proof in the decoction way brewed beer is lower by $0.4 \%$ due to its formula. Honey added to the hopped wort, or cold fermentation, will significantly affect the content of fermentable monosaccharides. An important part plays the fact whether the honey was treated by brewing together with the hopped wort, or added directly to the cold hopped wort for the main fermentation or getting fermented. These facts have an impact on the sensory value of the resulting beer, but this is not the target of our evaluation in this work. The content of monosaccharides and their rate of decline during fermentation affect the final content of oligosaccharides involved in the real extract of beer. Monosaccharides have a direct impact on the final content of ethanol, the higher their content in the malt wort, the more ethanol arises. This fact is highly significant $(p=0.000011)$ (Smogrovicova, 2001).

Tab. VI provides information about the content of oligosaccharides, maltose, glycerol and ethanol measured by liquid chromatography. Average contents of oligosaccharides and glycerol at $11^{\circ}$ beers from both the breweries practically do not differ from each other $(\mathrm{p}=0.666410, \mathrm{p}=0.732670)$. Apparent differences, however, can be found in the contents of maltose and ethanol $(p=0.010971$, $p=0.008612)$, which differentiate from average values by $0.07 \%$ in the case of maltose and by $0.3 \%$ as for alcohol. As for the $15^{\circ}$ special honey beer, the contents of maltose and glycerol differ from each other quite significantly ( $p=0.000154, p=0.000157$ ), on average by $0.3 \%$ as for maltose and by $0.25 \%$ as for glycerol. When comparing the contents of oligosaccharides and ethanol, the average values of beers from both the breweries are very close $(p=0.140558, p=0.05842)$ and at $95 \%$ of the level there can be found almost no difference.

Both kinds of the analyses, either by means of beer analyzer, or using liquid chromatography, support the general fact that beers produced by the decoction technique have less alcohol content, higher content of real extract and lower degree of fermentation in comparison with beers produced by the infusion method. In some cases, the values found in our measurements are close to the level of $95 \%$ and therefore of no significance and the impact of both the techniques of mashing, decoction and infusion, on the final quality of beer falls in a large part into the sensory characteristics of the sample beers (Rudnitskaya, 2009).

Infusion - our observations have noticed low levels of colour, bitterness and contents of total and oxidizable polyphenols, tannoids, anthocyangens, coluable nitrogen, cold break and wort solids in the Imhoff's cone. On the other hand, it showed the highest contents of alpha-glucans, DMS and PDMS in beer. As for the sensory evaluation, this proceeding has been judged in third place in overall ranking.

No particular fluctuations have been observed in results of the single mash decoction but the method has been found as the worst as far as sensory evaluation concerns.

Regarding the double mash decoction the results of the highest contents of total soluble nitrogen, total polyphenols as well as oxidized polyphenols. As for the sensory evaluation it took the second place in our list. 
The lowest contents of alpha-glucans, DMS and PDMS in the wort, DMS in beer, cold break, and wort solids in Imhoff's cone have been proven in using the triple mash decoction. On the other hand, this pro ceding gave the highest levels of colour, bitterness and content of FAN, coagulable nitrogen, tannoids and anthocyanogens. It ranked first in the sensory evaluation (Enge, 2005).

\section{CONCLUSION}

Two differently brewed beers have been observed for the aim of our study; one sample, taken at the Richard microbrewery, which uses double mash decoction technology for beer production, and the other at MENDELU brewery, with beer produced by means of the infusion method.

The decoction technique is much better suited for the Czech type of beer as during its production a number of agents arise thus positively affecting the sensory value of beer. For the aim of our comparison two kinds of beer have been chosen at each brewery, $11^{\circ}$ beer and special honey beer. In comparison to beers produced by infusion method, the decoction technique produced beers have generally higher levels of the real extract, lower degree of fermentation and lesser ethanol content. It is closely related to the way the mashing process is carried out, during which the particular mashes get boiled and affect the enzyme balance, which ultimately gives rise to a greater number of not fermented oligosaccharides and thus positively influences the fullness of the taste of beer. As for our comparison of two selected microbreweries, our findings of the observed parameters gave some conclusive results, such as in the case of the content of oligosaccharides and glycerol, but some showed statistically insignificant data, such as the content of ethanol and the real extract. This fact can also be attributed to the lack of homogeneity of individual brews, as the ratio of raw materials in particular batches is not always closely watched at microbreweries and thus the observed analytical parameters may show some fluctuations during the year.

\section{SUMMARY}

Within the frame of this work analytical parameters of microbrewery beers produced by the decoction and infusion methods have been measured. The microbrewery beer samples were taken at the Richard brewery (Brno-Žebětín) and at the microbrewery of Mendel University in Brno (MENDELU). The Richard brewery produces beers exclusively in double mash decoction manner, whereas the Mendelu brewery uses infusion method. The decoction method is more suitable for brewing Czech type beer, whereas the infusion method is used more for the production of western type of beer; this method is more energy - and time - saving and it is also often used in the Czech Republic. As for the Richard brewery beers, the following samples were taken: $12^{\circ}$ barley beer, $12^{\circ}$ cherry beer, $11^{\circ}$ wheat beer and $15^{\circ}$ honey beer. Samples taken at the MENDELU brewery consisted of $11^{\circ}$ barley beer and $15^{\circ}$ honey beer. Two methods of measuring have been used: by means of an automatic beer analyzer and by means of a high - pressure liquid chromatography. The obtained measured parameters have been compared and statistically processed while paying attention to the content of the real extract in beer, content of ethanol, original proof of the hopped wort, the degree of fermentation, and the content of oligosaccharides, maltose and glycerol.

A comparison of the beer samples from the two breweries reveals a statistically significant difference between $11^{\circ}$ Richard and $11^{\circ}$ MENDELU beer as far as the real extract is concerned, since the beer brewed by infusion technique (MENDELU) shows on average a value higher by $0.3 \%$. Parameters of both $15^{\circ}$ honey specials are significantly different from each other in the real extract content, ethanol content and original proof of hopped wort. The two $15^{\circ}$ honey specials do not differ significantly as far as the degree of fermentation is concerned. The real extract of the decoction method made beer is on average by $0.5 \%$ higher in comparison with the infusion technique, and also its alcohol content is higher by $0.2 \%$. The original proof of the decoction method made beer is lower by $0.4 \%$ due to its formula. Average contents of oligosaccharides and glycerol at $11^{\circ}$ beers from both the breweries practically do not differ from each other. There are significant differences, however, in the contents of maltose and ethanol, where the average different value amounts to $0.07 \%$ in the case of maltose and $0.3 \%$ as for alcohol. As for the $15^{\circ}$ special honey beers, highly significantly different levels of maltose and glycerol have been found, on average by $0.3 \%$ as for maltose and $0.25 \%$ as for glycerol. When comparing the content of oligosaccharides and ethanol in beers from both the breweries, the average values are very close to each other and at the level of $95 \%$ the difference is inconclusive.

Acknowledgement

This study was financed by the Internal Grant Agency of the Faculty of Agronomy MENDELU in Brno No. TP 7/2012. 


\section{REFERENCES}

BASAŘOVÁ, G., 2010: Teorie a praxe výroby piva, vydání 1., Praha, VŠCHT.

BLANCO - GOMIS, D., MANGAS - ALONSO, J., JUNCO - CORUJEDO, S., 2007: Cider proteins and foam characteristics: A contribution to their characterization. Journal of Agricultural and Food Chemistry, 55(7), 2526-2531.

CARVALHO, G., SILVA, D., BENTO, C., VICENTE, A., TEIXEIRA, J., FELIPE, M., 2009: Almeida J. Banana as Adjunct in Beer Production: Applicability and Performance of Fermentative Parameters. Appl. Biochem. Biotechnik, 356-365.

FREEMAN, G., J., LE GOURRIEREC, X., PATEL, A., 2003: Improving the effectiveness of isinglass finings for beer clarification by optimization of the mixing process. Part 1: Laboratory scale experiments. Journal of the Institute of Brewing, 109(4), 309-317.

FRITSCH, H., T., SCHIEBERLE, P., 2005: Identification based on quantitative measurements and aroma recombination of the character impact odorants in a Bavarian Pilsner - type beer. Journal of Agricultural a Food Chemistry, 53(19), 7544-7551.

KOLJONEN, T., HAMALAINEN, J., J., SJOHOLM, K., 1995: A model for the prediction of fermentable sugar concentration during mashing. Journal of Food Engineering. 26(3), 329-350.

MAC GREGOR, A., W., BAZIN, S., L., MACRI, L., J., 1999: Modeling the contribution of alpha amylase, beta - amylase and limit dextrinase to starch degradation during mashing. Journal of Cereal Science, 29(2), 161-169.

MONTANARI, L., FLORIDI, S., MARCONI, O., TIRONZELLI, M., FANTOZZI, P., 2005: Effect of mashing procedures on brewing. Eur Food Res Technol 221, 175-179.

OBRUCA, S., MAROVA, I., PARILOVA, K., 2009: A Contribution to Analysis of "Czech Beer" Authenticity. Czech Journal of Food Sciences 27, 323326.

OLIVEIRA, H., SEGUNDO, M., LIMA, J., GRASSI, V., ZAGATTO, E., 2006: Kinetic Enzymatic Determination of Glycerol in Wine and Beer Usány a Sequential Injection System with Spectrophotometric Detection, Journal of Agricultural and Food Chemistry, 54(12), 4136-4140.

RUDNITSKAYA, A., POLEHÁN, E., KIRSANOV, D., 2009: Instrumental measurement of beer taste attributes using an electronic tongue. Analytica chimica acta, 646 (1-2), 111-118.

SILVA, D., BRANYIK, T., DRAGONE, G., 2008: High gravity batch and continuous processes for beer production: Evaluation of fermentation performance and beer duality. Chemical papers 62(1), 34-41.

SMOGROVICOVA, D., DOMENY, Z., SVITEL, J., 2001: Modeling of saccharide utilization in primary beer fermentation with yeasts immobilized in calcium alginate. Applied biochemistry and biotechnology, 94(2), 147-158.

VERSTREPEN,K., J.,DERDELINCKX, G., DUFOUR, J., P., 2003: Flavor - active esters: Adding fruitiness to beer. Journal of Bioscience and Bioengineering, 96(2), 110-118.

ENGE, J., ŠEMÍK, P., KORBEL, J., ŠROGL, J., SEKORA, M.: Technologické aspekty infuzních a dekokčních způsobů rmutování. Kvas. Prum. 2005, 51(5), 158-165.

Ing. Pavel Kryl, Ústav zemědělské, potravinářské a environmentální techniky, Mendelova univerzita v Brně, Zemědělská 1, 61300 Brno, Česká republika, e-mail: kryl.pa@seznam.cz 